INSANIAH: Online Journal of Language, Communication, and Humanities Volume 4 (2), October 2021

\title{
Media Credibility, Misinformation, and Communication Patterns during MCO of COVID-19 in Malaysia
}

\author{
Mohammed Fadel Arandas \\ arandas@sc.edu.my \\ Southern University College, Malaysia \\ Loh Yoke Ling \\ lohyokeling@fbk.upsi.edu.my \\ Universiti Pendidikan Sultan Idris \\ Loh Yu Chiang \\ ycloh@sc.edu.my \\ Southern University College, Malaysia
}

\begin{abstract}
During Movement Control Order (MCO) of COVID-19, many information has been disseminated through both traditional and social media. Some of that information was credible and came from reliable sources while other information was fake and included misinformation, disinformation, and infodemic. The people needed credible information rather than fake one in this critical time. This study aimed to explore the credibility of media, information sources, the main issues, and preferred communication patterns and method of works perceived by Malaysians during MCO. A total of 300 questionnaires were distributed, and 210 were returned. The results of this study showed that the majority of respondents $69 \%$ relied on new media as their main source of information compared to $30.9 \%$ who relied on traditional media. However, a total of $64.8 \%$ of respondents considered traditional media as more credible and accurate compared to $35.2 \%$ for new media. Additionally, the main concerns and issues followed by respondents on media were health, economic, social, education and others. Finally, a total of $55.7 \%$ preferred face to face communication compared to $44.3 \%$ who preferred online communication. A total of $51 \%$ of respondents preferred to work from the workplace or office compared to $49 \%$ who preferred to work from home. Television played a significant role during the pandemic period due to its high credibility as perceived by Malaysians. The main intriguing implication of this study is considering the traditional media as more credible than social media by the Malaysians although the social media was their main source of information.
\end{abstract}

Keywords: Communication patterns; COVID-19; credibility; infodemic; misinformation

\section{INTRODUCTION}

The infectious coronavirus disease (COVID-19) caused by a recently discovered coronavirus (WHO, 2020d). The first discovered cases of COVID-19 were reported by officials in the Chinese Wuhan City in December 2019. Some of the earliest discovered cases were associated with the wholesale food market in the city. The market has been considered as the source of the virus or played an important role in the initial spread of the virus (WHO, 2020c). Then the virus spread to other countries and other imported cases were reported in January 2020 in some Asian countries such as Thailand, Japan, and Republic of Korea (WHO, 2020f).

Yet, the virus did not stop and continued its spread to reach other countries around the world including Malaysia. Increasing the number of reported cases in Malaysia has led the 
INSANIAH: Online Journal of Language, Communication, and Humanities

Volume 4 (2), October 2021

Malaysian Government to take several measures in its efforts to suppress the virus. One of the main measures was announcing the Movement Control Order (MCO).

The Movement Control Order (MCO) was implemented in Malaysia from 18 March 2020 to 31 March 2020 after the announcement of Malaysian Prime Minister Tan Sri Muhyiddin Yassin. It came after the increase of the number of Covid-19 cases in the country. The Malaysians were advised by the National Security Council (NSC) to not leave their homes except for important issues such as buying essentials, and to practice social distancing. All educational institutions and non-essential services sectors were ordered to shut down and all public gatherings were banned to minimise spreading of the virus (Ahmad, 2020). The issue of COVID-19 became totally ubiquitous and has changed the norms of day-to-day activities in the whole world including Malaysia. The use of media has increased by people whether to retrieve the information about the virus and the surrounding due to their staying at homes, or to work or study from their home instead of working from their offices.

The best way to slow down and prevent transmission of COVID-19 is being well informed about this virus, how it spreads, and the disease it causes (WHO, 2020d). The COVID-19 pandemic has severe economic, political, and social effects. It has also influenced systems of media and communication in unprecedented ways. This fast-evolving situation has led the traditional journalistic media to adopt with it, while alternative news media has given this situation their specific ideological spin on the internet. Criticism has been directed at such voices for spreading potentially fake news, conspiracy theories, and enhancing societal confusion via several online channels including social media (Boberg et al., 2020).

In addition, implementing the social distancing policy and lockdowns by many governments to stop the spread of the virus has many impacts on the life of people. They were forced to work, study, and even worship from their homes. This policy has changed the patterns of communication and increased the participation of people in communication technology (Putri \& Irwansyah, 2020).

This study aimed to explore the credibility of both traditional and new media, the sources of information, and the main issues and concerns of Malaysians during MCO of COVID-19. Also, the study examined the differences in the perception of Malaysians on the preferred communication patterns and method of work.

\section{Credibility}

A similarity was found between concept of credibility and believability or trust (Edelstein \& Tefft; 1974; Idid \& Wok 2006; Jackob, 2010; Metzger and Flanagin 2008; Morris, Counts, Roseway, Hoff \& Schwarz, 2012). Yet, the concept of credibility was considered by others as multidimensional rather than a single dimension. The definition of credibility came as a perceptual variable instead of being an objective measure for source or quality of information (Flanagin \& Metzger, 2007). Also, the definition of credibility as believability; credible information or people are the believable one (Tseng \& Fogg, 1999). Also, the credibility is defined as the quality worthy of trust or believable (Bucy, D'Angelo \& Bauer, 2014). The concept of credibility of a news story was also defined as a global estimation of the story objectivity (Sundar, 1999). The believability term is equal to credibility and it has been limited to source credibility (Edelstein \& Tefft, 1974).

In the research of communication and persuasion, credibility is an essential research area (Appelman \& Sundar, 2016). The academic literature on the topic of credibility goes back to the 1950s, and mainly came from the fields of psychology and communication. There was an agreement that the perceived quality is considered as credibility and it is not limited to a person, piece of information, or an object (Tseng \& Fogg, 1999). Media credibility is one of the most vastly studied areas in mass communication research. The topic of credibility has 
INSANIAH: Online Journal of Language, Communication, and Humanities

Volume 4 (2), October 2021

caused confusion and contradiction to several journalism professionals, scholars, and policy makers (McGrath \& Gaziano, 1986).

In Malaysia, the discussion about credibility of journalism, standards, and ethics was within the context of political expediency, corporate interests, and media control by laws (Anuar, 2010). There was a concern about the credibility of media since the more credible media has more effect on the people. The credibility of media is the understood believability degree of source of information by the audience. Credibility is the broadcasted or written report quality, and it is affected by several elements including relative expertise, accessibility, objectivity, report currency, and freedom to report. Assessing the credibility of information requires considering these factors (Idid \& Wok, 2006). Much of research of source effects came from interpersonal communication rather than mass communication settings (Edelstein $\&$ Tefft, 1974).

Recently, the people had various choices in their information seeking process. They can choose print media, broadcast, or even online media. Going online, give the people greater choices such as choosing the trusted sources news from the producers of independent media, follow the traditional journalism, or even from the "gatewatchers," who give instant punditry and watch the media gatekeepers (Banning \& Sweetser, 2007). For many decades, the main source of spreading information was the traditional mass media such as TV, newspaper, radio, and magazine. The main role has been played by traditional media was as societal watchdog and fourth estate of the field (Adeyanju, 2015).

The credibility of traditional media and more specific printed media has been seen as higher than the new media due to their approach and way in discussing different issues. Both credibility and social responsibility are the main factors that influence the popularity and prevalence of each type of media (Tanta, Barić-Šelmić \& Levak, 2017). There were two main factors that influenced the credibility of media, namely structural and technological features. Structural features: Explaining the high perceived believability of TV as proposed by some researchers might be through the stricter differences between the industries of TV and newspaper. Technological features: Initially, the thought of some researchers that the ability of bringing live news coverage for events by TV compared to newspaper was disadvantage since it might influence its accuracy (Metzger et al., 2003).

The traditional media such as TV, radio, and newspaper have been perceived as more credible than the new media such as online news portals, Internet, Twitter and Facebook by Malaysians. The most perceived highest credible medium was the TV, while the lowest perceived credible medium was Twitter. The low credibility for social media was due to the surrounding discussions on the issues of post-truth, false information, and fake news. In traditional media, the sources of content are mostly verified or known unlike the new media, which led to the poor evaluation of the new media credibility (Idid, Sannusi \& Arandas, 2019). The credibility of traditional media is still much higher than the credibility of new media. Also, the dependency of people on traditional media such as television and newspaper were much more than their dependency on the Internet (Mustaffa, et al., 2010).

A total of 225 misinformation pieces from English-language fact-checks were analysed and focused on content rated misleading or false. Most of them (88\%) have appeared on the platforms of social media, followed by $(9 \%)$ on $\mathrm{TV}$, then the news outlets and other websites figured (8\%) and (7\%) respectively. Rating the misinformation throughout this factsheet was based on the misleading or false information content as rated by independent professional fact-checkers (Brennen et al., 2020). The analysis of news coverage of COVID-19 shows that legacy media presents a higher percentage of satisfaction of people in their access to information through several platforms. Regarding the information confidence of people about the health emergency, network TV figured (82\%) then both TV 
INSANIAH: Online Journal of Language, Communication, and Humanities

Volume 4 (2), October 2021

and print media figured (75\%). In comparison, digital media has lower percentage $(62 \%)$ for websites and (64\%) for social media (Casero-Ripollés, 2020).

A series of studies about the dominant medium in the lives of audience started in 1959 then continued in 1963, 1974, and 1976 showed that the credible, dominant, believable was the TV. Among the American people, the TV still the main information sources and the most credible one (Roper, 1978). Among college students, the TV was perceived as the most credible news source compared the radio which was perceived as the lowest one. It might be due to the reason of exposing to TV by college students since their birth (Baxter \& Bittner, 1974). The credibility of TV was much than the credibility of the Internet. The media reliance, media usage, and issue salience have a significant relationship with the perception of people about the credibility of both TV and Internet (Mehrabi, Hassan \& Ali, 2009).

It is suggested that TV is more important, truthful, and credible than newspaper as a source of local news (Abel \& Wirth, 1977). TV was perceived by Malaysian youth as the most credible more than newspapers and Internet. Also, perceiving the TV as a credible medium has a positive relation with the consumption of people for TV news (Wok, Tamam \& Bolong, 2010). The TV was the main source of seeking entertainment compared to newspaper which was the main source of seeking information. People are less likely to focus on finding news error if they are in entertainment mode than when they are operating in the mode of processing of information (Mulder, 1980). Credibility among the needed types of information such as entertainment and news are different across the channels of media. Internet information was considered a credible as the other obtained information from TV, magazine and radio, but not high in credibility as newspaper information (Flanagin \& Metzger, 2000).

The news credibility of TV was totally much higher than the credibility of newspaper for around three decades. The judgment of people on the credibility of TV was varied from their judgment on newspaper. The immediate and dynamic nature of TV were the criteria of judgment on it, compared to the space and time separation between newspapers readers and producers. Thus, the newspaper was perceived as an organisational unit rather than individuals set (Newhagen \& Nass, 1989). The news of both TV and newspaper were considered as more credible than the news of social media since there was protection by welltrained staff besides their filtering to the news stories to ensure the accuracy and objectivity of news. The knowledge and educational level of the Internet has influenced the believability and choosing the news by people from newspaper, TV, and social media (Adeyanju, 2015).

Decreasing the circulation of mainstream newspapers has a relationship with their credibility. The perceived less credible media received less dependency by people on it. Yet, the television was more credible than Internet which requires improvement of its credibility (Salman et al, 2011). The credibility of newspaper has a negative relationship with structural pluralism in the United States. Ideology of conservative, use of newspaper, and social and political trust appeared to have significant relationship with the credibility of local newspapers. The decrease of credibility undermined the role of newspapers in informing the public about public affairs (Yamamoto \& Nah, 2017).

The embedment of mass-mediated communication comes from its medium. The perception and judgment of public about the news story in newspaper is based on their perception on the publisher, editor, and reporter of that story. Although two different newspapers have reported the same story that is related to one reporter and contains the same message, the perception and judgment might be different based on the news story itself (Appelman \& Sundar, 2016). Also, the negative evaluation of the credibility of a newspaper is a result of imbalanced structure of newspaper story (Fico, Richardson \& Edwards, 2004).

On the other hand, there was doubt about online information credibility from older journalists since the Internet includes much disseminated incorrect and false information 
INSANIAH: Online Journal of Language, Communication, and Humanities

Volume 4 (2), October 2021

despite the counter-attack efforts by online sites on their preforms against fake news (Vergeer, 2018). The organisation websites of news were different from personal websites of news regarding the perception about their credibility. The organisation websites have higher credibility than personal websites regarding the overall sponsor, credibility and message of the website (Flanagin \& Metzger, 2007).

For the Internet, credibility is a vital issue since the media that perceived as credible get more attention by people. The versions of both online and traditional media were considered as somewhat credible (Johnson \& Kaye, 1998). The rate of credibility was associated with other variables of using Twitter such as positive attitudes about instructors or who use Twitter or frequently tweet (DeGroot, Young \& VanSlette, 2015). Mostly, the readers use a group of features when making decision regarding credibility of tweet. The tendency of readers to be more trusting, probably due to the limited availability of explicit information about the author on Twitter (Shariff, Zhang \& Sanderson, 2017).

However, studying the concept of credibility was in two main areas, namely the credibility of the medium and the credibility of the source. The focus of medium credibility is on the channel that delivers the content more than focusing on the sender of content. The source credibility focuses on examining how different characteristics of the communicator can affect the processing of the message. Studying the source credibility was in massmediated contexts, organisational, and interpersonal, contexts (Kiousis, 2001).

The focus of medium credibility research is mainly on the medium of delivering the message to the audience such as TV or newspaper (Golan, 2010). Measuring the message credibility can be done by rating from participants about the degree that they think about the authenticity, believability and accuracy of the content. Thus, measuring the credibility of a message can be through the judgment of people about the content accuracy (Appelman \& Sundar, 2016). The focus of credibility of the message is mainly on the characteristics of messages can increase or decrease their credibility. The credibility of the message examines how the believability perception is influenced by characteristics of messages whether of the source's message or the source (Metzger et al., 2003).

On the other hand, in the process of communication, the credibility of the source is a significant element, and its literature mainly focuses on the persona. There should be expanded perspective for viewing the credibility especially when recognising the source are multidimensional (Bae, Wright \& Taylor, 2001). The focus of Research of source credibility concentrates is on the characteristics of message source such as the organisation, the news organisation, or the speaker (Golan, 2010).

The source credibility is the amount of believability or credibility referred to information source either individuals or mediums as perceived by receivers (Bracken, 2006). Using the credibility of term source was to imply the positive communicator characteristics that affect acceptance of the message by the receiver (Ohanian, 1990). Sources include a wide range of senders of message such as: News anchors, Websites, and news organisations (Yamamoto \& Nah, 2017).

\section{Misinformation and Infodemic}

In the middle of the unprecedented COVID-19 global health crisis, several policymakers, academics, and journalists have asserted that misinformation related to the pandemic shows a serious risk to public action and public health (Brennen et al., 2020).

Several misleading or false stories are shared and fabricated without any quality or background checking. The circulation of false and inaccurate information was about all the disease aspects such as the origins, causes, treatment of the virus, and its spreading 
INSANIAH: Online Journal of Language, Communication, and Humanities

Volume 4 (2), October 2021

mechanism. Absorbing and circulating misinformation can be very fast, change the behaviour of people, and probably lead them to have greater risks (PAHO, 2020).

Quick disseminating of accurate information became a necessity during the crises and epidemics. Yet, there are some barriers that must be overcome for taking the recommended action by people when they are accessing high-quality information. The fast spread of misinformation is similar to the pathogens which complicate the response of health emergency (WHO, 2020a). Spreading the misinformation through social media platforms is faster than spreading COVID-19 itself and can causes huge deleterious effects on health (Barua et al., 2020). The global misinformation epidemic disseminates quickly through several outlets and social media platforms poses a critical issue for public health (Zarocostas, 2020).

A mass circulation of falsehood has been spread as fast as the novel coronavirus itself which has reached almost every country in the world. The categorisation of circulation of falsehood was as disinformation by sharing and producing the information with malicious motivation and as misinformation by spreading the lies without any bad intentions (UNESCO, 2020). Differentiating misinformation from disinformation depends on the intention of the agent in sharing or producing inaccurate content. An example of disinformation is producing a content promising fake treatments of COVID-19 for private profit reasons but sharing the same content by some people as believed to be true with having the intention of being beneficial is misinformation (Posetti \& Bontcheva, 2020).

Spreading the misinformation by people comes intentionally through sharing them among the contacts of their network, and it is largely presumed that receiving and sharing misinformation by people as they find it veracious. Additionally, sharing misinformation by people not only because they believe that those information are true but might be due to other reasons such as sarcastic reasons, entertainment purposes, or even to challenge the misinformation. Thus, the alleged risk of fake news might be reduced or even reversed (Metzger \& Flanagin, 2020).

Sharing the content of misinformation and fake news through social media reduces the effectiveness of the policy of evidence-based interventions and undermine the scientific expertise credibility with possibility of longer-term consequences (Hartley \& Khuong, 2020). The increase of global access to social media, internet connection, and cell phones has led to the rapid production of information and the number of possible paths for having it, creating an infodemic or the epidemic of information (PAHO, 2020). The health crisis global scale, some world leaders, and social media contributions have worsened the current infodemic (France 24, 2020). Similar to the epidemic, the infodemic spreads between humans through physical information and digital systems. The escalation of infodemic phenomenon needs a coordinated response (WHO, 2020a).

The word "infodemic" came on 15 Feb 2020 during Munich Security Conference on the tongue of Tedros Adhanom Ghebreyesus, the Director-General of World Health Organisation (WHO) who said, "We're not just fighting an epidemic; we're fighting an infodemic." The term infodemic is an information overabundance that includes both accurate and inaccurate information which hardening for people to find reliable guidance and trustworthy sources when they need it. In the COVID-19 pandemic context, the global emergency scale has exacerbated the infodemic and increased by the interconnected way of consuming and disseminating the information through several channels including social media (WHO, 2020b).

The social media and technical risk communication teams of WHO have been working to respond and track the rumours and myths due to the high demands for trustworthy and timely information about COVID 19. Identifying the most spread rumours that have the possibility to harm the health of public such as false cures or prevention procedures was the 
INSANIAH: Online Journal of Language, Communication, and Humanities

Volume 4 (2), October 2021

focus of WHO through its offices and partners. Refuting these myths came through evidencebased information. WHO made public health advice and information and on COVID 19 that includes myth busters, available on its channels of social media such as Facebook, Twitter, Instagram, Pinterest, Weibo, LinkedIn, and website (WHO, 2020g).

Additionally, the Director-General of WHO said that the organisation is fighting the infodemic besides its fighting against the epidemic. Disseminating the fake news is more easily and faster than the virus, and it is dangerous as the virus itself. WHO worked with media and search companies such as Google, Facebook, Twitter, Tencent, TikTok, YouTube, Pinterest and others to face spreading misinformation and rumours (WHO, 2020e).

The role of social media in the dissemination of information communication has made it an ideal platform in disseminating the rumours. The early detection of rumours is debunking them at their stage of dissemination is known as early rumour detection comes through dealing with consecutive posts about disputed factual claims with highly textual duplication and certain variations over time. Identifying trending rumours requires a flexible and effective model that has the ability for getting long-range dependencies among postings and creating special representations for the right early detection (Chen et al., 2018).

The Malaysian Communications and Multimedia Commission (MCMC) has published research about spreading the fake news within the new media realm. The most used platform for spreading fake news was WhatsApp (84\%), then Facebook figured (8\%), followed by blogs and Twitter with (4\%) and (1\%) respectively (Hussain et al., 2019). More than 350 claims related to COVID-19 have been checked from the beginning until the middle of 2020 by MCMC. Additionally, over 260 papers related to fake news on COVID-19 have been investigated together with the Royal Malaysian Police (Zainul, 2020).

\section{Communication Patterns}

Currently, the advancement of technology has a strong influence on the way of communication between individuals. Bit by bit, the technology became an essential part of the way of communication between people and face-to-face communication has been taken a place increasingly this technology. The reliance on technology in communicating with family and friends has increased compared to the decrease of personal engagement with them which uninhibited by the use of devices and phones, even when in the situation of the presence of others (Drago, 2015).

Yet, many other people still prefer face-to-face communication over all other computer-mediated communication forms (Johnson, Sutton \& Poon, 2000). New technologies of communication have changed the use of communication media in organisations. However, face-to-face (FTF) communication perceived as an influential communication channel for employees despite the increase of using technology in organisations. In disseminating the work-related information and building relationship between managers and employees, FTF is considered as more effective than computermediated communication (CMC) although the CMC was the most used channel for employees (Lee, 2010).

Jonassen \& Kwon, (2001) stated that in the process of group problem-solving, FTF is more personal and cohesive compared to $\mathrm{CMC}$ which has clearer role expectations and more task oriented. The result of Okdie et al., (2011) shows that more positive impressions and interactions have been formed between participants who have FTF interaction comparing to others who have CMC interaction. Also, a better self-other agreement was found between FTF participants compared to CMC participants. The impressions of participants were similar to their partners during FTF interaction than CMC. The results revealed that FTF interaction 
INSANIAH: Online Journal of Language, Communication, and Humanities

Volume 4 (2), October 2021

which includes plenty of social cues made it a better channel for individuals to gauge characteristics of others (Okdie et al., 2011).

CMC has some technical limitations such as taking a long time to complete the allocated task than FTF and make less remarks in a given time period. These limitations lead to some consequences such as frustration with the medium and the poorer evaluations of the communication partner besides the medium itself. Thus, the tasks that require increased interdependence between groups cause a problem to the performance of CMC (Bordia, 1997). Johnson, Sutton, \& Poon, (2000) study revealed that overall, FTF is communication preferred by students compared to $\mathrm{CMC}$ although they use $\mathrm{CMC}$ for social bonding purpose. FTF allows transpiring both personal and non-verbal information and in synchronous setting and real time.

During COVID-19 pandemic, Work from Home (WFH) through CMC has mostly replaced FTF communication. WFH has both advantages and disadvantages for both organisations and employees. WFH through CMC that includes several technologies and mediums has created different climates and changes in communication patterns, but it was not richer than FTF communication. At least it has a significant role during the pandemic such as allowing the people to study and work from home, increasing the social connections between people, and providing much-needed entertainment and information (Putri \& Irwansyah, 2020).

\section{METHODOLOGY}

A total of 300 nationwide online questionnaires were distributed via Google form, yet the returned questionnaires were 210. Using an online google forms questionnaire was the safest and suitable way for data gathering due to the infection and spread of the virus in Malaysia. The Statistical Package for the Social Sciences (SPSS), version 23 has been used to analyse the collected data for this study. The data analysis relied on descriptive including percentages and frequencies.

\section{RESULTS AND DISCUSSIONS}

\section{Demographic Characteristics}

The total number of respondents was 210 . Table 1 shows the demographic characteristics of the respondents. The female respondents figured $56.2 \%$ compared to $43.8 \%$ for male respondents. The vast majority of respondents $81 \%$ aged between $18-30$ years, followed by $12.9 \%$ for those from 31-40. Finally, the respondents aged between $41-50$ and $51 \&$ above were $3.3 \%$ and $2.9 \%$ respectively.

Regarding the race of respondents, the Chinese race was the most dominant with $89.0 \%$, followed by Malay then Indian with $6.2 \%$ and $4.8 \%$ respectively. The respondents who gained between RM2000 and less monthly income shaped $66.7 \%$, followed by $17.6 \%$ for those who gained from RM2001-RM3000. Respondents who gained between RM4001RM5000 and RM3001-RM4000 were 5.7\% and 5.2\% respectively. Finally, those who gained RM5001 \& above shaped $4.8 \%$.

Table 1. Demographic profile of respondents

\begin{tabular}{|lcc|}
\hline Items & Frequency & Percentage \\
\hline & Gender & \\
\hline Female & 118 & 56.2 \\
Male & 92 & 43.8 \\
\hline
\end{tabular}


INSANIAH: Online Journal of Language, Communication, and Humanities

Volume 4 (2), October 2021

\begin{tabular}{|lcc|}
\hline & Age & \\
\hline $18-30$ & 170 & 81.0 \\
$31-40$ & 27 & 12.9 \\
$41-50$ & 7 & 3.3 \\
$51 \&$ above & 6 & 2.9 \\
\hline & Race & 89.0 \\
\hline Chinese & 187 & 6.2 \\
Malay & 13 & 4.8 \\
Indian & 10 & \\
\hline & Highest Education & 26.7 \\
\hline High School & 56 & 34.8 \\
Diploma & 73 & 35.7 \\
Bachelor's degree & 75 & 2.4 \\
Postgraduate & 5 & .5 \\
Others & 1 & 66.7 \\
\hline & 140 & 17.6 \\
\hline RM2000 and less & 37 & 5.2 \\
RM2001 - RM3000 & 11 & 5.7 \\
RM3001 - RM4000 & 12 & 4.8 \\
RM4001 - RM5000 & 10 & $\mathbf{1 0 0 . 0}$ \\
RM5001 \& above & $\mathbf{2 1 0}$ & \\
\hline Total & & Monthlycome \\
\hline
\end{tabular}

\section{Media Credibility, Reliance, and Concerns}

Table 2 presents the source of information, media credibility, and concerns during COVID19. Most of the respondents $69 \%$ relied on social media as their main source of daily information, followed by $20 \%$ for TV. Then, newspaper and radio figured $5.7 \%$ and $5.2 \%$ respectively. However, a total of $42.9 \%$ of respondents considered the TV as the most credible and accurate medium, followed by social media especially Facebook and Instagram, and newspaper with $27.1 \%$ and $17.1 \%$ respectively. The less credible mediums for respondents were the official government websites and radio with $8.1 \%$ and $4.8 \%$ respectively. Additionally, respondents were asked an open-ended question about the reasons for trusting one medium than another. Their answer was that they trust TV rather than social media due spreading large amount misinformation, disinformation and fake news on social media. The respondents accessed the media to know about some specific issues and concern. The most prevalent issue was the health issue with $40 \%$ followed by economic and social issues with $37.6 \%$ and $11 \%$ respectively. Finally, education figured $9.5 \%$ and other issues were $1.9 \%$.

Table 2. Source of information, media credibility, and concerns

\begin{tabular}{lcc}
\hline Items & Frequency & Percentage \\
\hline Social media & Main source of daily information \\
TV & 145 & 69.0 \\
Newspaper & 42 & 20.0 \\
Radio & 12 & 5.7 \\
\hline \multicolumn{3}{c}{ Credibility and accuracy of media } \\
\hline TV & 90 & 5.2 \\
Social media & 57 & 42.9 \\
\hline
\end{tabular}


INSANIAH: Online Journal of Language, Communication, and Humanities

Volume 4 (2), October 2021

\begin{tabular}{lcc}
\hline Newspaper & 36 & 17.1 \\
Official govt. websites & 17 & 8.1 \\
Radio & 10 & 4.8 \\
\hline \multicolumn{3}{l}{ Main concerns and issues during MCO } \\
\hline Ecalth & 84 & 40.0 \\
Social & 79 & 37.6 \\
Education & 23 & 11.0 \\
Others & 20 & 9.5 \\
Total & 4 & 1.9 \\
\hline
\end{tabular}

\section{Patterns of Communication}

Table 3 describes the communication patterns and preferred medium of communication and work during COVID-19. A total of $55.7 \%$ of respondents preferred face to face communication method compared to $44.3 \%$ who preferred online communication with others. Additionally, a total of $51 \%$ of respondents preferred to work from office or workplace compared to $49 \%$ who preferred to work from home. Finally, the vast majority of respondents $71 \%$ agreed that staying with their family has improved their relationships and ties, compared to $29 \%$ who have disagreed.

Table 3. Communication patterns

\begin{tabular}{|c|c|c|}
\hline Items & Frequency & Percentage \\
\hline \multicolumn{3}{|c|}{ Preferable medium of communication } \\
\hline Face to face & 117 & 55.7 \\
\hline Online & 93 & 44.3 \\
\hline \multicolumn{3}{|c|}{ Preferable method of work } \\
\hline From workplace/ office & 107 & 51.0 \\
\hline From home & 103 & 49.0 \\
\hline \multicolumn{3}{|c|}{ MCO and improving relationship with family } \\
\hline Yes & 149 & 71.0 \\
\hline No & 61 & 29.0 \\
\hline Total & 210 & 100.0 \\
\hline
\end{tabular}

The respondents of this study have perceived the TV as the most credible medium. In this study, the results were in line with previous studies (Baxter \& Bittner, 1974; Idid, Sannusi \& Arandas, 2019; Wok, Tamam \& Bolong, 2010). Additionally, previous studies (Armstrong \& Collins, 200; Wanta \& Hu, 1994; Westley \& Severin, 1964; Yamamoto \& Nah, 2017) argued that reliance on media by the audience has a correlation with its accepted credibility.

However, the majority of respondents (69\%) used social media as their main source of information rather than other mediums although they considered the TV as the most credible medium (42.9\%). This might be attributed to the interests and demographics of respondents especially their age since the majority of them $(81 \%)$ belong to millennials who have been born from the years 1981-1996 and generation $\mathrm{Z}$ who have been born from the years 19972010. Both millennials and generation $Z$ rely heavily on social media compared to Baby Boomers and generation X. As discussed by Kuyucu, (2016) that social media became the favourite media of the new generations. The new generations prefer social media rather than traditional media which cause a threat to traditional media. Different generations have 
INSANIAH: Online Journal of Language, Communication, and Humanities

Volume 4 (2), October 2021

various ways and motivations in their use of online media. The known traditional communication means are replaced slowly by the new digital tools (Fietkiewicz et al., 2016).

Additionally, most of the respondents' preferred face to face (FTF) communication compared to computer mediated communication (CMC), more than half preferred to work from office rather than home, and finally, the vast majority agreed that staying with family members during MCO has improved the family relations. It can be understood that FTF communication still occupies a significant aspect in the daily life of respondents despite their use of CMC.

\section{CONCLUSION}

The aim of this study was to explore the media credibility, information sources, and the main concerns of Malaysians during MCO. Also, the study examined the preferred method of work and communication patterns. The results of this study revealed that media use was not related to media credibility, but to the interests of respondents. Although the TV was perceived as the most credible medium the respondents relied more on social media. Additionally, the news consumption by Malaysians during MCO of COVID-19 was about health issues followed by economic, social, education, and other issues.

On the other hand, spreading misinformation, disinformation, and fake news as mentioned by WHO mainly came through social media rather than traditional media. However, since social media became the main source of information, thus decision-makers and stakeholders such as health authorities and MCMC can disseminate their messages through online TV streaming or TV accounts on several social media platforms. This approach can increase the use of TV as the most credible medium and refute the misinformation and infodemic.

Additionally, refuting and debunking the misinformation and fake news about COVID-19 requires a high level of coordination and arrangement from all countries, governments, official bodies, and organisations especially media sector at both international and local levels. Fact-checking of the information besides identifying the fake news by them might reduce the severity of spreading such harmful information and thus reduce the harm of COVID-19 itself.

\section{REFERENCES}

Abel, J. D., \& Wirth, M. O. (1977). Newspaper vs. TV credibility for local news. Journalism Quarterly, 54(2), 371-375.

Adeyanju, A. (2015). Comparative study of social media, television and newspapers' news credibility. International Conference on Communication, Media, Technology and Design. Dubai, United Arab Emirates, pp 69-77.

Ahmad, S. (2020, March 18). Just stay home, NSC reminds Malaysians. New Straits Times. $\begin{array}{lllll}\text { Retrieved } & 28 & \text { Nov } & 2020 & \text { from }\end{array}$ https://www.nst.com.my/news/nation/2020/03/575748/just-stay-home-nsc-remindsmalaysians

Anuar, M. K. (2010). Commentary: Teaching 'best practices' of journalism in Malaysia. Asia Pacific Media Educator, 1(20), 177-182.

Appelman, A., \& Sundar, S. S. (2016). Measuring message credibility: Construction and validation of an exclusive scale. Journalism \& Mass Communication Quarterly, 93(1), 59-79.

Armstrong, C. L., \& Collins, S. J. (2009). Reaching out: Newspaper credibility among young adult readers. Mass Communication and Society, 12(1), 97-114. 
INSANIAH: Online Journal of Language, Communication, and Humanities

Volume 4 (2), October 2021

Bae, S. W., Wright, L. B., \& Taylor, R. D. (2001). Print advertising context effects: the influence of media credibility on advertisement credibility. Journal of Promotion Management, 6(1-2), 73-88.

Banning, S. A., \& Sweetser, K. D. (2007). How much do they think it affects them and whom do they believe?: Comparing the third-person effect and credibility of blogs and traditional media. Communication Quarterly, 55(4), 451-466.

Barua, Z., Barua, S., Aktar, S., Kabir, N., \& Li, M. (2020). Effects of misinformation on COVID-19 individual responses and recommendations for resilience of disastrous consequences of misinformation. Progress in Disaster Science, 8, 100119.

Brennen, J. S., Simon, F., Howard, P. N., \& Nielsen, R. K. (2020). Types, sources, and claims of COVID-19 misinformation. Reuters Institute, 7, 3-1.

Boberg, S., Quandt, T., Schatto-Eckrodt, T., \& Frischlich, L. (2020). Pandemic populism: Facebook pages of alternative news media and the corona crisis--A computational content analysis. arXiv preprint arXiv:2004.02566.

Bordia, P. (1997). Face-to-face versus computer-mediated communication: A synthesis of the experimental literature. The Journal of Business Communication, 34(1), 99-118.

Bracken, C. C. (2006). Perceived source credibility of local television news: The impact of television form and presence. Journal of Broadcasting \& Electronic Media, 50(4), 723-741.

Bucy, E. P., D’Angelo, P., \& Bauer, N. M. (2014). Crisis, credibility, and the press: A priming model of news evaluation. The International Journal of Press/Politics, 19(4), 453-475.

Casero-Ripollés, A. (2020). "Impact of Covid-19 on the media system. Communicative and democratic consequences of news consumption during the outbreak". El profesional de la información, 29, (2), 1-11.

Chen, T., Wu, L., Li, X., Zhang, J., Yin, H., \& Wang, Y. (2018). Call attention to rumors: Deep attention based recurrent neural networks for early rumor detection. Pacific-Asia conference on knowledge discovery and data mining. Springer, Cham, pp. 40-52.

DeGroot, J. M., Young, V. J., \& VanSlette, S. H. (2015). Twitter use and its effects on student perception of instructor credibility. Communication Education, 64(4), 419-437.

Drago, E. (2015). The effect of technology on face-to-face communication. Elon Journal of Undergraduate Research in Communications, 6(1), 13-19.

Edelstein, A. S., \& Tefft, D. P. (1974). Media credibility and respondent credulity with respect to Watergate. Communication Research, 1(4), 426-439.

Fico, F., Richardson, J. D., \& Edwards, S. M. (2004). Influence of story structure on perceived story bias and news organization credibility. Mass Communication \& Society, 7(3), 301-318.

Fietkiewicz, K. J., Baran, K. S., Lins, E., \& Stock, W. G. (2016). Other times, other manners: How do different generations use social media. Hawaii University International Conferences, Honolulu, Hawaii, pp. 1-17.

Flanagin, A. J., \& Metzger, M. J. (2000). Perceptions of Internet information credibility. Journalism \& Mass Communication Quarterly, 77(3), 515-540.

Flanagin, A. J., \& Metzger, M. J. (2007). The role of site features, user attributes, and information verification behaviors on the perceived credibility of web-based information. New Media \& Society, 9(2), 319-342.

France 24 (2020). Conspiracy theories and fake news: Fighting the Covid-19 'infodemic'. Retrieved 28 Nov 2020 from https://www.france24.com/en/20200426-conspiracytheories-and-fake-news-fighting-the-covid-19-infodemic 
INSANIAH: Online Journal of Language, Communication, and Humanities

Volume 4 (2), October 2021

Golan, G. J. (2010). New perspectives on media credibility research. American Behavioral Scientist, 54(1), 3-7.

Hartley, K., \& Khuong, V. M. (2020). Fighting fake news in the COVID-19 era: policy insights from an equilibrium model. Policy Sciences, 53(4), 735-758.

Hussain, S. A. E., Kilagwa, R. T., Zaali, Y. M., Wok, S. (2019). The effect of message credibility on media use and perception of fake news among students. Human Communication, 1(2), 1-21.

Idid, S. A., \& Wok, S. (2006). Credibility of television, newspaper and Internet with popular votes of Barisan National during elections by race. Jurnal Pengajian Media Malaysia: Malaysian Journal of Media Studies, 8(1), 41-56.

Idid, S. A., Sannusi, S. N., \& Arandas, M. F. (2019). Reliance media exposure and credibility. International Conference on Media and Communication (MENTION 2019). Universiti Kebangsaan Malaysia, Tenera Hotel, Bangi, pp 626-644.

Jackob, N. G. E. (2010). No alternatives? The relationship between perceived media dependency, use of alternative information sources, and general trust in mass media. International Journal of Communication, 4(18), 589-606.

Johnson, D. M., Sutton, P., \& Poon, J. (2000). Face-to-Face vs. CMC: Student communication in a technologically rich learning environment. The $17^{\text {th }}$ Annual Conference of the Australian Society for Computers in Learning in Tertiary Education: ASCILITE 2000. Southern Cross University Press, Lismore, pp. 509-520.

Johnson, T. J., \& Kaye, B. K. (1998). Cruising is believing?: Comparing Internet and traditional sources on media credibility measures. Journalism \& Mass Communication Quarterly, 75(2), 325-340.

Jonassen, D. H., \& Kwon, H. (2001). Communication patterns in computer mediated versus face-to-face group problem solving. Educational Technology Research and Development, 49(1), 35-51.

Kiousis, S. (2001). Public trust or mistrust? Perceptions of media credibility in the information age. Mass Communication \& Society, 4(4), 381-403.

Kuyucu, M. (2016). The social media generation: social media use in Turkey in the sample of Istanbul. IOSR Journal of Humanities and Social Science, 21(2), 84-98.

Lee, C. E. (2010). Face-to-face versus computer-mediated communication: Exploring employees' preference of effective employee communication channel. International Journal for The Advancement of Science \& Arts, 1(2), 38-48.

McGrath, K., \& Gaziano, C. (1986). Dimensions of media credibility: Highlights of the 1985 ASNE survey. Newspaper Research Journal, 7(2), 55-67.

Mehrabi, D., Hassan, M. A., \& Ali, M. S. S. (2009). News media credibility of the internet and television. European Journal of Social Sciences, 11(1), 136-148.

Metzger, M. J., \& Flanagin, A. J. (2008). Digital media, youth, and credibility. London: MIT press.

Metzger, M. J., Flanagin, A. J., Eyal, K., Lemus, D. R., \& McCann, R. M. (2003). Credibility for the $21^{\text {st }}$ century: Integrating perspectives on source, message, and media credibility in the contemporary media environment. Annals of the International Communication Association, 27(1), 293-335.

Metzger, M. J., \& Flanagin, A. J. (2020). Understanding how communication about misinformation can help to combat it. The Harvard Kennedy School Misinformation Review, 1 (8), 5-6.

Meyen, M., \& Schwer, K. (2007). Credibility of media offerings in centrally controlled media systems: a qualitative study based on the example of East Germany. Media, Culture \& Society, 29(2), 284-303. 
INSANIAH: Online Journal of Language, Communication, and Humanities

Volume 4 (2), October 2021

Morris, M. R., Counts, S., Roseway, A., Hoff, A., \& Schwarz, J. (2012). Tweeting is believing?: understanding microblog credibility perceptions. ACM 2012 conference on Computer Supported Cooperative Work. Washington, pp.441-450.

Mulder, R. (1980). Media credibility: A use-gratifications approach. Journalism Quarterly, 57(3), 474-477.

Mustaffa, N., Ibrahim, F., Samani, M. C., \& Rahim, M. H. A. (2010). Persepsi Khalayak Terhadap Kredibiliti Media di Malaysia. Jurnal eBangi, 5(2), 153-160.

Newhagen, J., \& Nass, C. (1989). Differential criteria for evaluating credibility of newspapers and TV news. Journalism Quarterly, 66(2), 277-284.

Ohanian, R. (1990). Construction and validation of a scale to measure celebrity endorsers' perceived expertise, trustworthiness, and attractiveness. Journal of Advertising, 19(3), 39-52.

Okdie, B. M., Guadagno, R. E., Bernieri, F. J., Geers, A. L., \& Mclarney-Vesotski, A. R. (2011). Getting to know you: Face-to-face versus online interactions. Computers in Human Behavior, 27(1), 153-159.

PAHO (2020). Understanding the infodemic and misinformation in the fight against COVID19. Retrieved 11 Dec 2020 from https://iris.paho.org/bitstream/handle/10665.2/52052/Factsheet-infodemic_eng.pdf

Posetti, J \& Bontcheva, K. (2020). Disinfodemic: Deciphering COVID-19 disinformation: brief 1. UNESCO. Retrieved 28 Nov 2020 from https://en.unesco.org/sites/default/files/disinfodemic_deciphering_covid19_disinforma tion.pdf

Putri, A. V., \& Irwansyah, I. (2020). Communication patterns and media technology role in organization and society during pandemic. The Journal of Society and Media, 4(2), 228-261.

Roper, B. W. (1978). Changing public attitudes toward television and other media1959-1976. Communications, 4(2), 220-238.

Salman, A., Ibrahim, F., Abdullah, M. Y. H., Mustaffa, N., \& Mahbob, M. H. (2011). The impact of new media on traditional mainstream mass media. The Innovation Journal: The Public Sector Innovation Journal, 16(3), 1-11.

Shariff, S. M., Zhang, X., \& Sanderson, M. (2017). On the credibility perception of news on Twitter: Readers, topics and features. Computers in Human Behavior, 75, 785-796.

Sundar, S. S. (1999). Exploring receivers' criteria for perception of print and online news. Journalism \& Mass Communication Quarterly, 76(2), 373-386.

Sweetser, K. D., Porter, L. V., Chung, D. S., \& Kim, E. (2008). Credibility and the use of blogs among professionals in the communication industry. Journalism \& Mass Communication Quarterly, 85(1), 169-185.

Tanta, I., Barić-Šelmić, S., \& Levak, T. (2017). The Level of Credibility of Traditional and New Media in Reporting on Human Rights Issues. Collegium Antropologicum, 41(3), 215-229.

Tseng, S., \& Fogg, B. J. (1999). Credibility and computing technology. Communications of the ACM, 42(5), 39-44.

UNESCO (2020). Journalism, press freedom and COVID-19. Retrieved 28 Nov 2020 from https://en.unesco.org/sites/default/files/unesco_covid_brief_en.pdf

Vergeer, M. (2018). Incorrect, fake, and false. Journalists' perceived online source credibility and verification behavior. Observatorio $\left(O B S^{*}\right), 12(1), 37-52$. 
INSANIAH: Online Journal of Language, Communication, and Humanities

Volume 4 (2), October 2021

Wanta, W., \& Hu, Y. W. (1994). The effects of credibility, reliance, and exposure on media agenda-setting: A path analysis model. Journalism Quarterly, 71(1), 9098.

Westley, B. H., \& Severin, W. J. (1964). Some correlates of media credibility. Journalism Quarterly, 41(3), 325-335.

WHO (2020a). $1^{\text {st }}$ WHO infodemiology conference: How infodemics affect the world \& how they can be managed. Retrieved 28 Nov 2020 from https://www.who.int/docs/defaultsource/epi-win/infodemic-management/infodemiology-preconferencebooklet.pdf?sfvrsn=200223d5_2

WHO (2020b). Coronavirus disease 2019 (COVID-19) Situation Report - 86. Retrieved 28 Nov 2020 from https://www.who.int/docs/default-source/coronaviruse/situationreports/20200415-sitrep-86-covid-19.pdf

WHO. (2020c). Coronavirus disease 2019 (covid-19) situation report - 94. Retrieved 28 Nov 2020 from https://www.who.int/docs/default-source/coronaviruse/situationreports/20200423-sitrep-94-covid-19.pdf

WHO (2020d). Coronavirus: Overview. Retrieved 28 Nov 2020 from https://www.who.int/health-topics/coronavirus\#tab=tab_1

WHO (2020e). Munich Security Conference. Retrieved 28 Nov 2020 from https://www.who.int/director-general/speeches/detail/munich-security-conference

WHO (2020f). Novel coronavirus (2019-nCoV). Situation report-1. Retrieved 28 Nov 2020 from https://www.who.int/docs/default-source/coronaviruse/situationreports/20200121-sitrep-1-2019-ncov.pdf

WHO (2020g). Novel Coronavirus (2019-nCoV) Situation Report - 13. Retrieved 28 Nov 2020 from https://www.who.int/docs/default-source/coronaviruse/situationreports/20200202-sitrep-13-ncov-v3.pdf

Wok, S., Tamam, E., \& Bolong, J. (2010). Pattern of the news media consumption and news discussion among youth: A test of agenda setting theory. International Communication and Media Conference (ICOME"10) Communication and Society: Challenges and Engagement. Universiti Utara Malaysia (UUM), Kuala Lumpur, pp. 1-25.

Yamamoto, M., \& Nah, S. (2017). A multilevel examination of local newspaper credibility. Journalism \& Mass Communication Quarterly, 95(1), 76-95.

Zarocostas, J. (2020). How to fight an infodemic. The Lancet, 395(10225), 676.

Zainul, H. (2020, July 2). More must be done to address Covid- 19 infodemic. New Straits $\begin{array}{lllll}\text { Times. } & \text { Retrieved } & 28 & \text { Nov } & 2020\end{array}$ https://www.nst.com.my/opinion/columnists/2020/07/605200/more-must-be-doneaddress-covid-19-infodemic 